
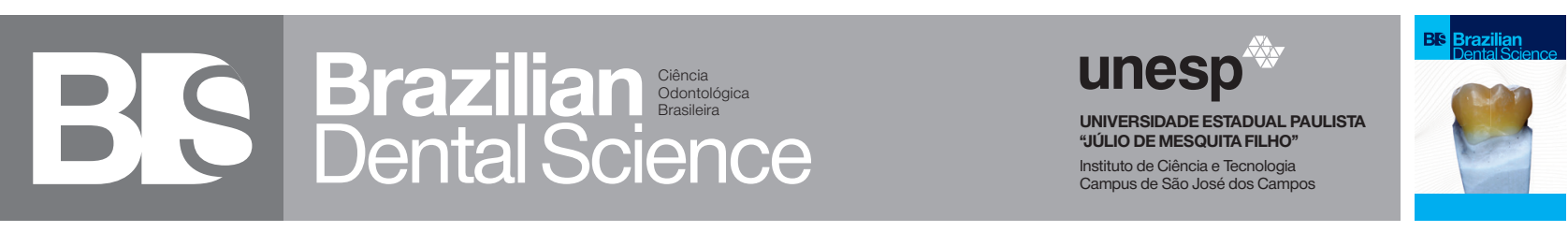

\title{
Diagnostic value of magnetic resonance imaging in the analysis of ameloblastoma: report of two cases
}

Valor diagnóstico da ressonância magnética na análise do ameloblastoma: relato de dois casos

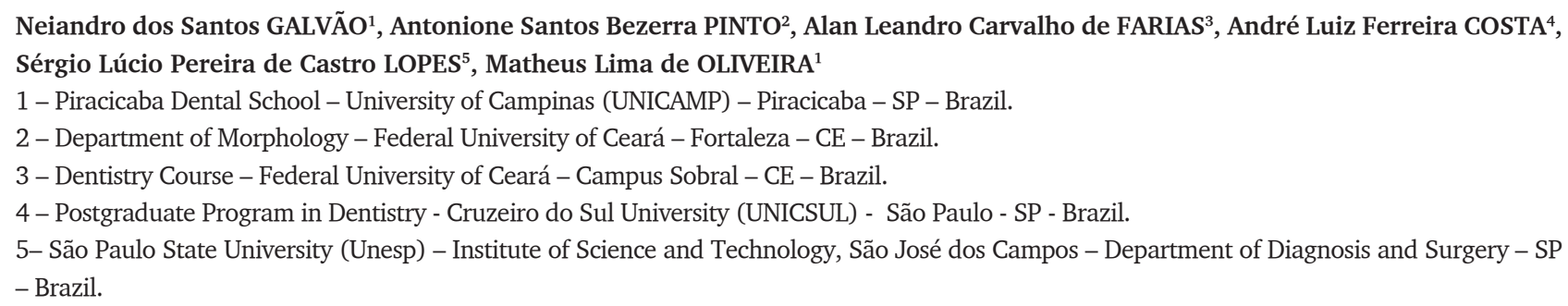

\section{ABSTRACT}

Ameloblastoma is an odontogenic tumor that shares clinical and imaging characteristics with other lesions of the jaws, such as odontogenic keratocyst, which makes the diagnosis difficult.However, in addition to radiographic and tomographic examinations, Magnetic Resonance Imaging (MRI) has been increasingly used, contributing with relevant additional information about thedifferentiation between solid and liquid components of the lesion. This case report was conducted to present two variations of ameloblastoma and discuss the radiographic, tomographic and MRI contribution in the differential diagnosis between ameloblastoma and odontogenic keratocyst. The signal intensity in T1-weighted MRI revealed internal fluid content in both cases, which was important in the differential diagnosis with other intraosseous lesions such as odontogenic keratocysts. This is probably due to the presence of keratin that increases the viscosity of the content and also for an intermediate signal intensity signal in T2-weighted MRI. Therefore, MRI revealed important internal characteristics of the reported lesions, which was very useful in the establishment of the differential diagnosis with other lesions.

\section{KEYWORDS}

Ameloblastoma; Odontogenic keratocyst; Magnetic resonance imaging; Diagnosis.

\section{RESUMO}

O ameloblastoma é um tumor odontogênico que compartilha características clínicas e de imagem com outras lesões da mandíbula, como o ceratocisto odontogênico, o que dificulta o seu diagnóstico. Entretanto, além dos exames radiográficos e tomográficos, a ressonância magnética (RM) tem sido cada vez mais utilizada, contribuindo com informações adicionais relevantes sobre a diferenciação entre componentes sólidos e líquidos da lesão. Este relato de caso apresenta duas variações de ameloblastoma e discuti a contribuição radiográfica, tomográfica e da RM no diagnóstico diferencial entre o ameloblastoma e o ceratocisto odontogênico. A RM ponderada em $\mathrm{T} 1$ revelou conteúdo líquido interno em ambos os casos relatados, o que foi importante no diagnóstico diferencial com outras lesões intraósseas, como os ceratocistos odontogênicos. Isto ocorre devido à presença de queratina aumentar a viscosidade do conteúdo e também gerar um sinal de intensidade intermediária na RM ponderada em T2. Portanto, a RM revelou importantes características internas das lesões relatadas, o que foi muito útil no estabelecimento do diagnóstico diferencial com outras lesões.

\section{PALAVRAS-CHAVE}

Ameloblastoma; Ceratocisto odontogênico; Ressonância magnética; Diagnóstico. 


\section{INTRODUCTION}

A wide variety of benign tumors can affect the gnathic bones and present similar clinical and imaging features[1].For example, the ameloblastomaoriginates from odontogenic epithelial cells and is the second most prevalent odontogenic tumor of the jaws, after only odontoma[1,2].This tumor is commonly aggressive and located in the posterior mandible[1,2].In 2017, the World Health Organization proposed a new classification of head and neck tumors, and ameloblastoma was then subdivided into ameloblastoma (previously classified as solid or multicystic), unicystic, peripheral and metastatic[3].Although the subdivisions of ameloblastoma share etiological and some clinical and radiographic characteristics, different therapeutic approaches are neededfor a good prognosis, which highlights the importance ofidentifying each condition[1-3].

In recent years, Magnetic Resonance Imaging (MRI) has been increasingly used to evaluate maxillofacial cysts and tumors [4,5].The imaging features of lesions such as odontogenic keratocyst and ameloblastoma in MRI have been published by many authors [4-7]. However, some morphological characteristics are very similar, which makes the diagnosis difficult in many cases[6,7].Cystic or predominantly cysticameloblastomas are often misdiagnosed as locally aggressive odontogenic keratocysts [6]. In such cases, accurate preoperative diagnosis can help treatment planning, since therapeutic options are different for each condition [7].

MRI is a useful imaging modality in the analysis of internal structures of a lesion because it provides high contrast resolution of soft tissues [4-7].Different acquisition parameters used in MRI provide an additional information in the internal characterization of lesions, such as ameloblastoma and odontogenic keratocyst [47]. Therefore, this case report was conducted to present different radiographic and tomographic behaviors of ameloblastoma and the additional information that can be obtained from MRI in the differential diagnosis of this condition.

\section{Case history}

This report of two cases was approved by the local Ethics Research Committee (protocol \# 2.024.954) andboth patients signed informed consent for the use of clinical, laboratory, histopathological and imaging data.

\section{Case 1 - Ameloblastoma}

A 50-year-old brown male patientcame to the dental office with pain in the left mandible after the extraction of a residual dental root. Clinically, a hard swelling was present in the region of left lower molars. Panoramic radiographic examination (Figure 1A) revealed an extensive multilocular welldemarcated radiolocencyin the left posterior mandibular body, angle and ramus. To have a volumetric assessment of the lesion,cone-beam computed tomography (CBCT) was obtained using the i-CAT GXCB-500(Imaging Sciences International, Hatfield, PA, USA) with a field of view of $16 \times 6 \mathrm{~cm}$ (diameter $\mathrm{x}$ height) and voxel size of $0.2 \mathrm{~mm}$. The CBCT images (Figure $2 \mathrm{~A}$ and B) revealed a hypodense area with loculations, important expansion of the buccal and lingual cortices, and involvement of the mandibular canal.Interruption of lingual cortex was observed; however, partial volume averaging artifact should be considered for structures smaller than the voxel size $(0.2 \mathrm{~mm})$ [8].The highly hipodense area located in the upper part of the lesion indicates the biopsy region. Then, in order to assessthe soft tissue components of the lesion, multiplanar MRIwas also obtained usingthe Achieva1.5T unit (Phillips, Andover, MA, USA), with a magnetic field of $1.5 \mathrm{~T}$ and a specific skull coil. The following parameters were used: T1-weighted images (spin eco) with a repetition time of $478 \mathrm{~ms}$, echo time of $16 \mathrm{~ms}$, slice thickness of $2.0 \mathrm{~mm}$, field of view of 21 x $21 \mathrm{~cm}$; T2-weighted images (spinecho)with a 
repetition time of $6.5 \mathrm{~ms}$, echo time of $90 \mathrm{~ms}$, slice thickness of $2.0 \mathrm{~mm}$, field of view of $21 \times 21 \mathrm{~cm}$. The T1-weighted MRI showed a circumscribed lesion of intermediate signal (Figure 3A).The T1weighted MRI SPIR (Figure 3B) and T2-weighted SPIR MRI showed regions of hypersignal within the lesion,indicating the presence offluid (Figure $3 \mathrm{~B}$ and C).Histopathological examination showed plexiform growth pattern with islands of epithelial and peripheral basaloid cells showing reverse nuclear polarizationand areas of anastomosis ofperipheral epithelial cells of basaloid morphology, which confirmed the diagnosis of ameloblastoma (Figure 4A and B).

\section{Case 2 - Ameloblastoma unicístico}

An18-year-old white male patient came to the dental office with a slow growing asymptomatic swelling in the left mandible. Clinically, the patient presented with facial asymmetry and a hard mass in the alveolar ridge near the first and second left lower molars. Panoramic radiographic examination (Figure 1B) revealed an extensive radiolucent, unilocular, well-demarcated andcorticated image, causing partial root resorption of the lower left first and second molars,apical displacement of the third molarand expansion of the base of the mandible. In order to evaluate the lesion in the three dimensions and its relationship with adjacent structures, CBCT scan was obtained with the same parameters as in case 1. CBCT images (Figure 2C and D) revealed a hypodense area with severe expansion, thinning of the buccal and lingual cortices, root resorption of the lower left first and second molars, inferior displacement of the mandibular canal and apical displacement of the third molar to the base of the mandible.In order to better conduct the differential diagnosis and to evaluate the internal aspect of the lesion, MRI images were obtained with the same parameters as in case 1.The CBCT images were obtained after incisional biopsy, which justifies the highly hypodense component in the lesion. The T1-weighted MRIshowed a circumscribed lesion with intermediate signal (Figure 3D). The T2-weighted MRIFLAIR showed regions of high signal intensity, which reveals liquid content, as well as a specific region of low signal intensity related to the incisional biopsy (Figure 3E e F).Histopathological examination revealed basal cell nuclei in palisade position with reverse polarization, cells that resemble stellate reticulum, and luminal proliferation.Thus, the finaldiagnosis was unicystic ameloblastoma (Figure 4C and D).

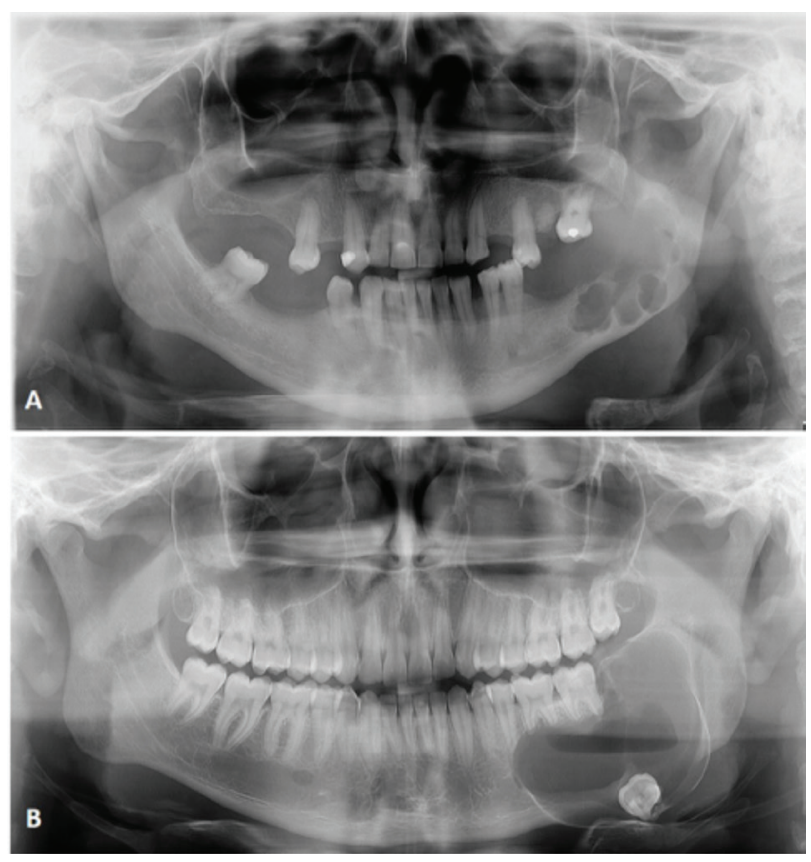

Figure 1 - Panoramic radiographs: A- Case 1, multilocular radiolucent image; $\mathrm{B}$ - Case 2 , well-defined unilocular corticated radiolucent image. 

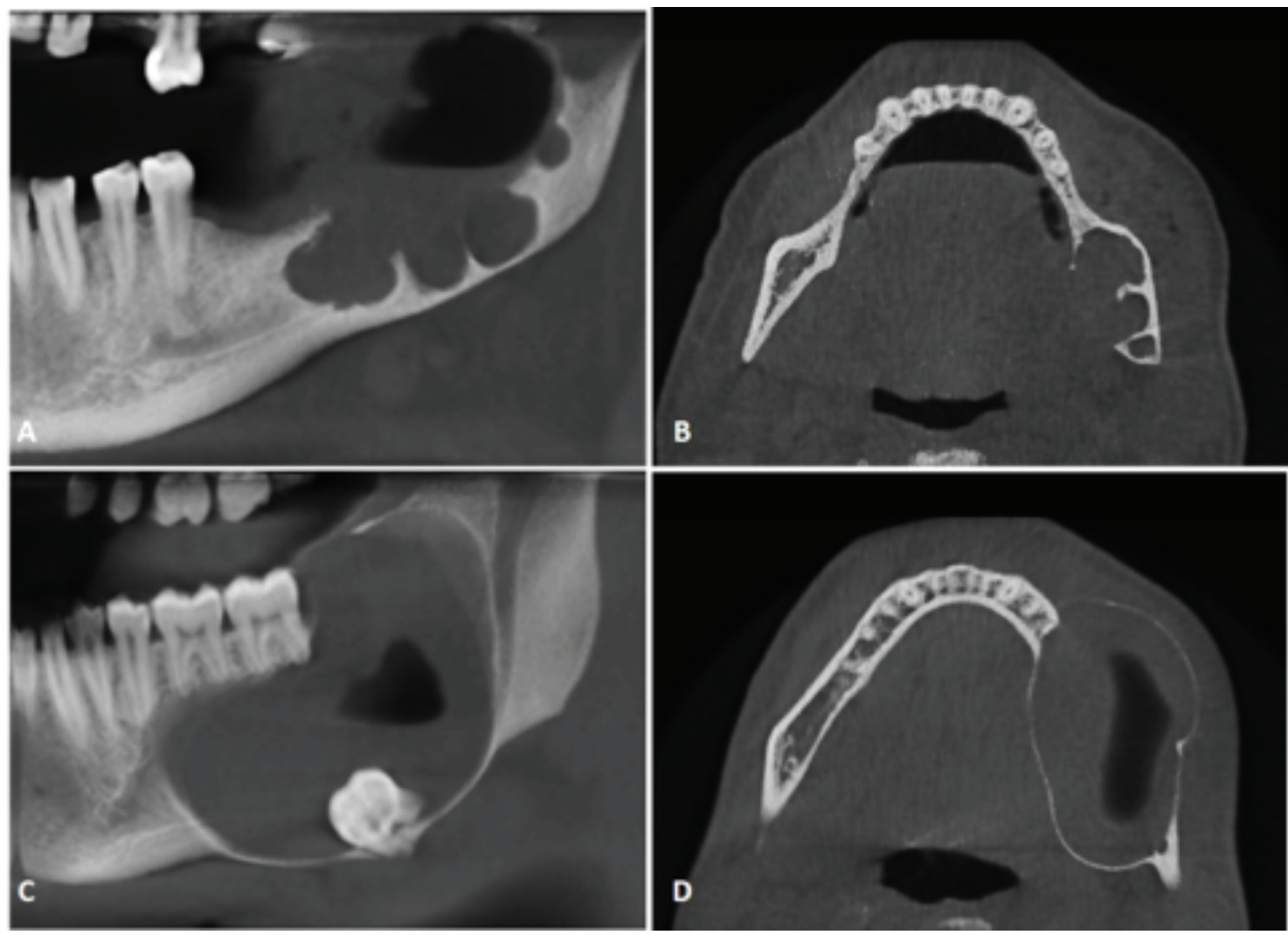

Figure 2 - СВСТ: A- Case 1, multiloculated hypodense image; B- Case 1, expansion of lingual cortical bone; C- Case 2, hypodense unilocular image with apical displacement of the lower left third molar; D- Case 2, important cortical bone expansion.
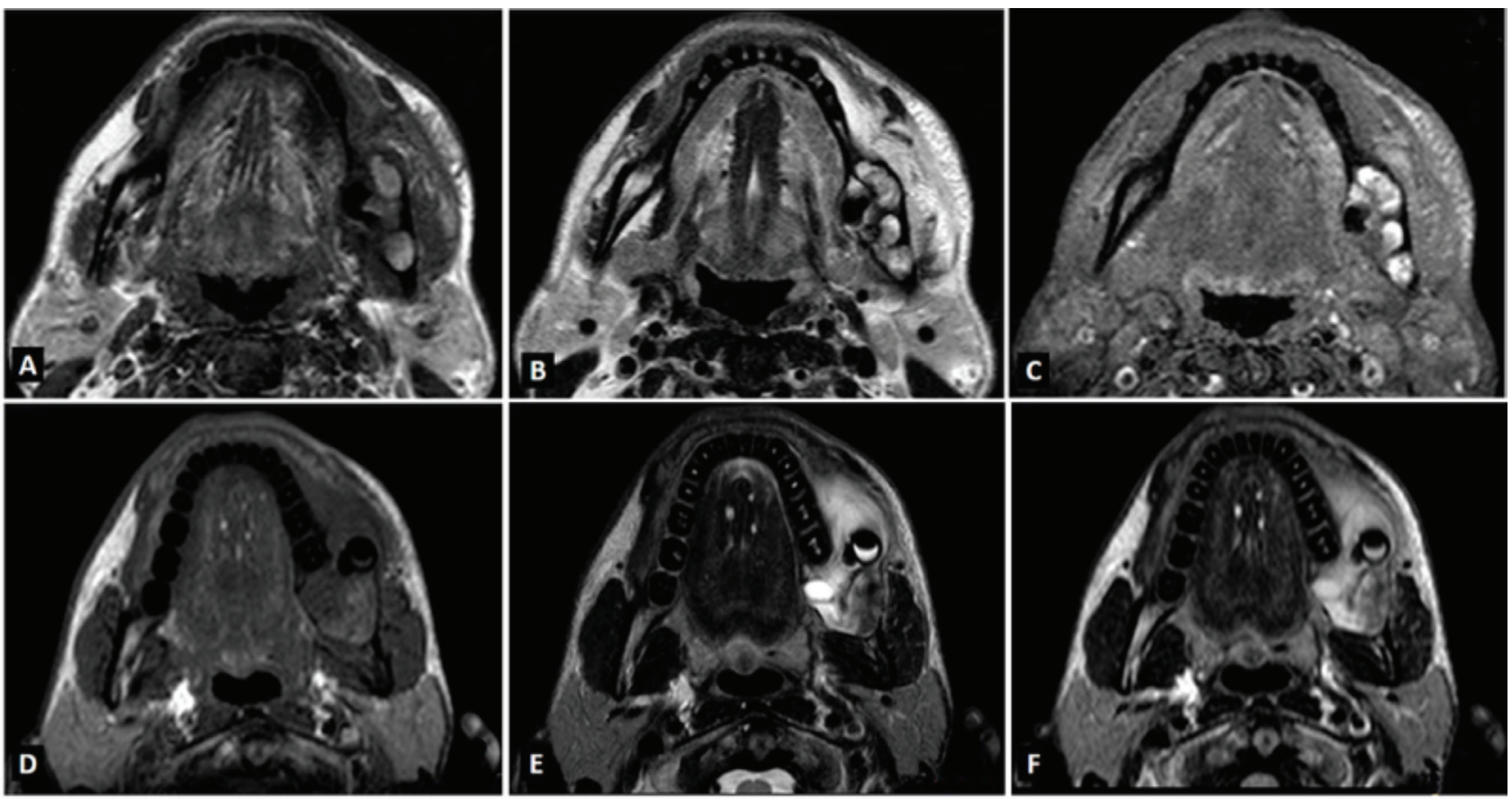

Figure 3 - MRI: A- case 1, isointense homogeneous tumor; B and C- case 1, heterogeneous isointense and hyperintense areas; Dcase 2 homogeneous isointense tumor; $\mathrm{E}$ and $\mathrm{F}$ - case 2, heterogeneous isointense and hyperintenseareas. 

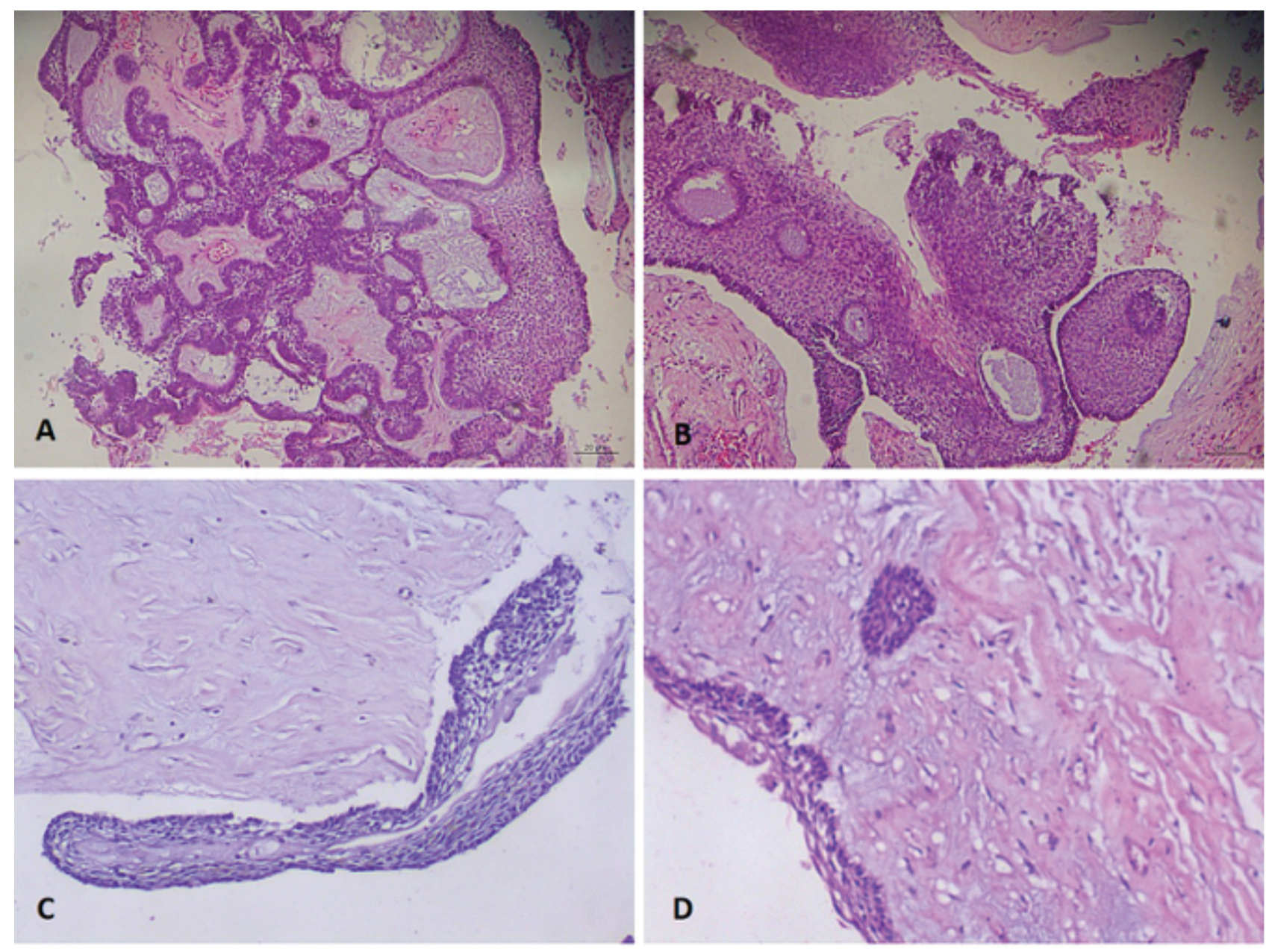

Figure 4 - Histopathological findings (hematoxylin and eosin staining, x200 magnification): A and B -case 1, islands of epithelial and peripheral basaloid cells; C and D - case 2, basal cell nuclei in palisade position with reverse polarization.

\section{DISCUSSION}

Imaging examinations are very important in the diagnostic process in Dentistry, with emphasis to radiographic examination due to the ease of access and relative technical simplicity [9].These factors allowed radiographic aspects of lesions in the jaws to be well established in the scientific literature, such as those of ameloblastoma, which is described as a radiolucent lesion of well-defined limits, preferably located in the posterior mandible. This lesiontends to cause bone expansion of the buccal and lingual cortices, root resorption and tooth impaction. The ameloblastoma may be multiloculated (soap bubble or honeycomb aspect, depending on the size of the loculations); however, it may present with a unilocular aspect, which, in some cases, exhibit scalloped margins [1$3]$.

The radiographic aspects of ameloblastoma, together with clinical characteristics, help the dentist to determine the differential and presumptive diagnosis. However, the limitations of the radiographic technique may hinder surgical planning and treatment, since the lesion cannot be assessed volumetrically $[1,2,9]$.Thus, limitations regarding the superimposition of structures observed in radiographic examinations were overcome by CBCT, which provides threedimensional information of dentomaxillofacial 
structures in real size [9].The tomographic aspect of ameloblastoma has been described as a well-defined hypodense image with cortical expansion without perforation, which may be multilocular or unilocular depending on the type $[3,9]$. The contributions of CBCT in some cases are more expressive for surgical planning thanfor diagnosis, since the differential diagnosis of multilocular ameloblastoma (myxoma, odontogenic keratocyst and giant cell central lesion) and unilocular ameloblastoma (dentigerous cyst, ameloblastoma and odontogenic keratocyst) will not differ substantially from those raised by clinical and radiographic examination, as observed in the present case [3,9].

As another imaging modality, MRIhas shown important impact in the differential diagnosis and therapeutic planning for providing information about soft tissue without exposing the patient to ionizing radiation.Many scientific studies [4-6], have been documented with the aim of establishing a patter of MRI signal intensity to differentiate odontogenic lesions; however, it is worth mentioning that MRI presents very limited access due to the high cost and consequent low availability.

It is important to emphasize that the final diagnosis is determined by histopathological examination. The determination of the most consistent presumptive diagnosis is important because it optimizestreatment planning of patients who will have, as a consequence, a more specific therapeutic approach because, despite sharing clinical and radiographic characteristics, the treatment of the lesions can differ substantially [1-3].

The MRI sequences of the two lesions presented in this report provided additional information when compared to CBCT.These sequencesproduced images with different phase changes between water and fat saturation to better characterize the internal components of the lesion. In the T2-weighted MRI, the signal intensity of the ameloblastoma was intermediate to high. Instead, the unicystic ameloblastoma presented high homogeneous signal intensity. Odontogenic cysts and unilocular ameloblastomas usually present intermediate homogeneous signal intensity in T1-weighted MRI. Ameloblastoma shows intermediate signal intensity in both the cystic and solid portion andthe heterogeneous pattern observed within this tumor mass is due to the multicystic and solid structure.

The signal intensity in T1-weighted MRIrevealed internal fluid content in both cases, which was important in the differential diagnosis with other intraosseous lesions such as odontogenic keratocysts. This is probably due to the presence of keratin that increases the viscosity of the content and also for an intermediate signal intensity signal in T2weighted MRI. Therefore, MRI revealed important internal characteristics of the reported lesions, which was very useful in the establishment of the differential diagnosis with other lesions. For a better understanding, a table comparingkeratocyst, ameloblastoma and odontogenic myxoma using CT and MRI exams was produced (Table 1 ).

Table 1- Comparative data between keratocyst, ameloblastoma and odontogenic myxoma using CT and MRI exams

\begin{tabular}{|c|c|c|}
\hline & CT & MRI \\
\hline Keratocyst & $\begin{array}{l}\text {-hypodense image, heterogenic } \\
\text { internal content; } \\
\text {-uni or multilocular corticated } \\
\text { boundaries; } \\
\text {-well-defined lesion with less corti- } \\
\text { cal thinning and expansion; } \\
\text {-less tendency to reabsorb teeth } \\
\text { and delocate them. }\end{array}$ & $\begin{array}{l}\text {-hyposignal in T1 } \\
\text { and T2 weighted } \\
\text { images,showing } \\
\text { possible signs of } \\
\text { internal hetero- } \\
\text { geneity. }\end{array}$ \\
\hline $\begin{array}{c}\text { Ameloblas- } \\
\text { toma }\end{array}$ & $\begin{array}{l}\text {-hypodense image, usually multilo- } \\
\text { cular, hyperdense curved septa; } \\
\text {-tendency to thin the bone cortices; } \\
\text {-tendency to erosion of the tooth } \\
\text { reabsorb teeth and move them. }\end{array}$ & $\begin{array}{l}\text {-hyposignal in } \\
\text { T1-weighted } \\
\text { images and } \\
\text { T2-weighted } \\
\text { images, showing } \\
\text { a mixed solid and } \\
\text { cystic pattern. }\end{array}$ \\
\hline $\begin{array}{l}\text { Odontoge- } \\
\text { nic } \\
\text { Myxoma }\end{array}$ & $\begin{array}{l}\text {-hypodense image, usually multilo- } \\
\text { cular, thin and straight hyperdense } \\
\text { septa; } \\
\text {-tendency to thin the bone cortices. }\end{array}$ & $\begin{array}{l}\text {-hyposignal in T1 } \\
\text { and T2 weighted } \\
\text { images, showing } \\
\text { internal homoge- } \\
\text { neity. }\end{array}$ \\
\hline
\end{tabular}




\section{REFERENCES}

1. Bilodeau EA, Collins BM. Odontogenic Cysts and Neoplasms. Surg Pathol Clin. 2017 Mar;10(1):177-222. doi:10.1016/j.path.2016.10.006. Epub 2016 Dec 29.

2. Parmar S,Al-Qamachi L, Aga H.Ameloblastomas of the mandible and maxilla. CurrOpinOtolaryngol Head Neck Surg. 2016 Apr;24(2):148-54. doi: 10.1097/ M00.0000000000000238.

3. Wright JM, Vered M. Update from the 4th Edition of the World Health Organization Classification of Head and Neck Tumours: Odontogenic and Maxillofacial Bone Tumors. Head Neck Pathol. 2017 Mar;11(1):68-77. doi: 10.1007/s12105-017-0794-1. Epub 2017 Feb 28.

4. Pinto AS, Costa AL, Galvão ND, Ferreira TL, Lopes SLVValue of Magnetic Resonance Imaging for Diagnosis of Dentigerous Cyst. Case Rep Dent. 2016;2016:2806235. Epub2016 Sep 27.

5. Fujita M, Matsuzaki H, Yanagi Y, Hara M, Katase N, Hisatomi M, etal. Diagnostic value of MRI for odontogenic tumours. DentomaxillofacRadiol. 2013;42(5):20120265. doi: 10.1259/dmfr.20120265. Epub 2013 Mar 6.
6. Gamba Tde0,Flores IL,Pinto AB, Costa AL, Moraes ME,Lopes SL.Keratocystic odontogenic tumor: role of cone beam computed tomography and magnetic resonance imaging. Gen Dent. 2016 Jan-Feb;64(1):36-9.

7. Kirtaniya BC, Sachdev V, Singla A, Sharma AK. Marsupialization: a conservative approach for treating dentigerous cyst in children in the mixed dentition.J Indian Soc PedodPrev Dent. 2010 Jul-Sep;28(3):203-8. doi:10.4103/09704388.73795 .

8. Schulze R, Heil U, Gross D, Bruellmann DD, DranischnikowE, Schwanecke U, et al. Artefacts in CBCT: a review. DentomaxillofacRadiol. 2011 Jul;40(5):265-73. doi: 10.1259/dmfr/30642039.

9. White SC, Pharoah MJ. The evolution and application of dental maxillofacial imaging modalities. Dent Clin North Am. 2008 0ct,52(4):689-705, v. doi: 10.1016/j.cden.2008.05.006.

\section{Dr. Neiandro dos Santos Galvão}

\section{(Corresponding address)}

DDS, MSc, PhD in Oral Radiology, UNICAMP - University of Campinas, Piraci-

caba Dental School

Av. Limeira, 901 - Areião, Piracicaba - SP, 13414-018.

+55 (19) 2106-5724

Date submitted: 2019 Mar 25

neiandrogalvao@gmail.com

Accept submission: 2019 May 30 